\title{
Phenotypic Analysis of Seed Yield and Yield Components in Cowpea (Vigna unguiculata L., Walp)
}

\author{
Olawale Mashood Aliyu ${ }^{1,2 *}$, Bukola Oluwaseun Makinde ${ }^{1}$ \\ ${ }^{1}$ Department of Crop Production, Kwara State University, Malete 23431, Nigeria \\ ${ }^{2}$ Department of Cytogenetics and Genome Analysis, Institute of Plant Genetics and Crop Plant Research (IPK), Gatersleben 06466, \\ Germany
}

\begin{abstract}
Poor seed yield remains a great challenge for cowpea production in sub-Sahara Africa and continuous evaluation of available genetic resource to develop high and stable yielding varieties is the panacea to this regional food security conundrum. In this study, 21 cowpea breeding lines were evaluated for phenotypic analysis of seed yield components for two years in a randomized complete block design of 3 replications. All the yield components exhibited significant genotypic variation, while flowering, pod maturity and seed yield traits recorded significant variation for years and its interactions. These cowpeas, which are predominantly early-medium maturing biotypes, exhibited relative phenotypic stability for the yield components across years (seasons) except seed yield, being a final product of complex physiological process. Relationships between flowering/pod maturity and seed size were positive and significant. By contrast, pods/plant, seeds/plant and total seed yield recorded negative correlations with pod maturity. However, seeds/plant and pods/plant are the most contributory components to seed-yield with correlation coefficients of $r=0.95,0.89$, respectively. Although seed size had negative correlation with seeds/pod, but strong linkage between seed number (seeds/pod, seeds/plant) and seed yield; and additive gene nature of seed size, suggest a weak size-number trade-off in cowpea. Genetic variance components indicates high genetic contributions over non-genetic to plant phenotypic variability with high heritability values (0.75-0.91). Six cowpea lines (IT10K-837-1, IT07K-299-6, IT10K-815-5, IT10K-817-7, IT08K-150-24, and IT11K-61-82) with multiple quality yield traits could be selected for immediate farmers use and future genetic improvement.
\end{abstract}

Keywords Cowpea variety (Vigna unguiculata), Genetic and phenotypic variability, Seed yield components, Yield stability.

\section{INTRODUCTION}

Cowpea (Vigna unguiculata L. Walp.), is an important staple food legume and cheap source of protein for many poor Africans in the low-land humid and dry savannah tropics. It is an excellent substitute for animal proteins by resource-poor people and vegetarians because of its high seed protein content (about 25\%) and rich amino acids (Alghali 1991; Boukar et al. 2011). Indeed, some cultivars with seed protein content of about $30 \%$, close to that obtained for soybean (Glycine max) have been reported (Singh 2007; Santos et al. 2012). Immature pods, immature seeds and young leaves of cowpea are also used as vegetables (Umaharan et al. 1997), and its plant residues could be used as fodders and compost. Nigeria accounts for about $50 \%$ of total cowpea production in Africa with production of about 6 million metric tons (FAO 2013, www.faostat.fao.org; website visited 23 June, 2015). This high volume of production demonstrate the importance of cowpea cultivation as a component of Nigerian farming system and with cultivation expanding beyond northern region traditionally known for the crop in recent time (Nwofia et al. 2006; Akande et al. 2012). However, farmers-traditional cultivars are known to be well adapted to the low input conditions, but generally poor in yield and highly susceptible to the major diseases and pests. These production constraints are the main target of cowpea breeding program both at the national and regional levels in sub-Sahara Africa. Although past research efforts have brought some improvement into farmer's yield, but avail-

Received April 15, 2016; Revised April 29, 2016; Accepted May 3, 2016; Published May 31, 2016

*Corresponding author Olawale Mashood Aliyu, walealiyu@mail.com, Tel: +234-8039548344, Fax: +234-8039548344 
able statistics still indicate significant instability in yield across years (FAO 2013) and yield at farm-gate is far below optimum.

Yield has been described as a complex phenotypic trait in plants because it is a final aggregate product of many interwoven physiological and development traits controlled by different arrays of genes. Understanding interrelationship among these component constituents (yield component traits) (Oladejo et al. 2011) and the environment (Nwofia 2012) is vital to achieving high and stable yield. Genetic studies in cowpea have largely focused on inheritance and additive-dominant models through generation mean analysis of crossed parents (Sene 1968; Aryeetey and Laing 1973; Warner and Honma 1980; Drabo et al. 1984; Drabo et al. 1985). However, recent advances in genomics have implicated epigenetics in plant gene-trait(s) breakdown and/or loss through time (Pikaard and Scheid 2014). In addition, unregulated seed distribution system and limitation in resources (human and capital) to research centers had led to poor release and distribution of 'improved' varieties with doubt on genetic integrity and yield stability. This problem could be addressed through a decentralized system where improved lines from research and seed centers are subjected to post-varietal-release evaluation to ascertain genetic stability, in this case yield and yield components. In this study, 21 improved cowpea lines at advanced stage of breeding were evaluated for genetic stability of seed yield and yield components traits under a southern guinea savannah ecology using variance component analysis approach in a search for cowpea varieties with stable high yield under this agro-ecological condition.

\section{MATERIALS AND METHODS}

Field trials were carried out at the Teaching and Research Farm, of the Kwara State University, Malete, (Latitude $08^{\circ} 26^{\prime} \mathrm{N}$; Longitude $04^{\circ} 29^{\prime} \mathrm{E}$ ), about $345 \mathrm{~m}$ above sea level in the southern guinea savanna agro-ecology of Nigeria. The study was carried out for 2 years (2013 and 2014) and plantings were done on the 1st day of July (i.e., when rain was steady) each year. Twenty-one (21) improved cowpea breeding lines collected from the International Institute of Tropical Agriculture (IITA), Ibadan were used for this study. These materials are in advance stage of breeding and yet to be released to public. Further information on pedigree and date of varietal release could be sourced from IITA. The field trial was laid out as a randomized complete block design (RCBD) of twenty-one (21) treatments (breeding lines/varieties) and each treatment replicated thrice. Each plot consists of 2 rows of $10 \mathrm{~m}$ length with $1.0 \mathrm{~m}$ of alley between plots. About 2 to 3 seeds were planted per hole at spacing of $0.3 \times 0.6 \mathrm{~m}$ and were later thinned down to one after 2 weeks of germination, thus, giving effective plant population of about 55,555 plant $\mathrm{ha}^{-1}$. The experimental plots were manually weeded twice and plants were sprayed with cypermethrin ${ }^{\mathrm{TM}}$ at the rate of $20 \mathrm{~g}$ active ingredient $\mathrm{ha}^{-1}$, initially at 3 weeks after germination and subsequently for every fortnightly until pod maturity to prevent insect pest infestation that is prevalent in the region.

Data were collected on 50 days to flowering, $50 \%$ days to pod maturity, peduncles per plant, pods clustering per peduncle, pod length $(\mathrm{cm})$, pods per plant, seeds per pod, 100-seed weight $(\mathrm{g})$, seeds per plant, and seed-grain yield per plant from which yield per hectare $(\mathrm{kg})$ was estimated at $13 \%$ moisture content (dry weight basis). Summarized data were statistically analysed for combined analysis of variance (ANOVA) of RCBD using Costat statistical program (CoStat Incorporation) and Duncan's multiple range test for mean separation. Variance components (phenotypic variance, genotypic variance, and error variance) of the total phenotypic variability were estimated from the analysis of variance using model 3 (Prasad et al. 1981; Wricke and Weber 1986). Phenotypic coefficients of variation and genotypic coefficient of variation (GCV) were computed from variance components (Johnson et al. 1955; Kumar et al. 1985) and broad sense heritability (repeatability) was calculated as described by Allard (1999).

\section{RESULTS}

The analysis of variance showed highly significant genotypic effect for all the characters (Table 1), indicating 


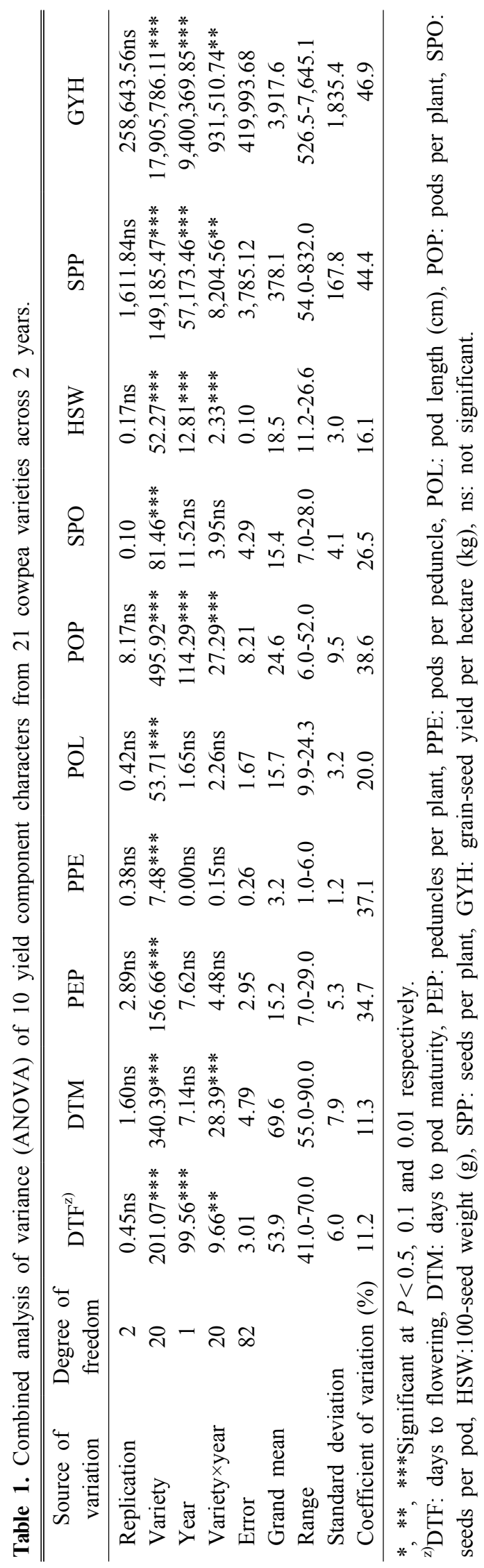

that the 21 cowpea varieties genetically differ in maturity period, expression of yield components and total seed yield production. Except for days to maturity, peduncles/plant, pods per peduncle, and pod length, other 6 yield components were significantly different $(P<0.01)$ across years and similar pattern recorded for variety $\times$ year. The degree of variation of these yield components were presented as range values and subsequently summarized as coefficients of variation (\%) (Table 1). Days to flowering and maturity recorded least variations, about $11 \%$ (coefficient of variation) each, in the contrast to seed yield per hectare, seeds per plant, and pods per plant with higher CVs of $46.9 \%, 44.4 \%$, and 38.6, respectively (Table 1). The range values recorded for flowering (41-70 days) and pod maturity (55-90 days) suggest that the varieties are predominantly early to medium maturing biotypes (Table 1). Range values for others yield components indicated that the selected cowpeas comprise of low to very high yielding biotypes (Table 1).

Performance (mean values) across years for days to flowering and pod maturity data showed that 2013 plantings attained anthesis 2 days earlier than 2014 plantings; however there was no difference in pod maturity time between the two years (Table 2). Sowings were done in the month of July when rain is steady and sufficient moisture critical for cowpea growth is already established. Similarly, mean data for peduncles per plant, pods per peduncle, pod length, and seeds per pod recorded no significant variation across the two years (Table 2). However, yield components like pods per plant, seed size (100-seed weight), seeds per plant and seed yield per hectare, recorded a relatively better (significant) performance in 2013 for compared to 2014 (Table 2), with difference of about $7.4 \%, 3.4 \%, 10.7 \%$, and $13.0 \%$, respectively. Among the 21 cowpea plants, IT10K-827-11, and IT10K-837-1 ranked best in terms of precocity i.e., earliness to flowering at about 45 days and $<60$ days pod maturity (Table 2). However, for seed yield and yield components, IT11K-61-82 stands out as the best, with combination of highest peduncles per plant (26.0), pods per peduncle (4.6), pod length $(21.5 \mathrm{~cm})$, pods per plant (43.7), seeds per plant (755.0), and total seed yield $\left(6,732 \mathrm{~kg} \mathrm{ha}^{-1}\right)$ (Table 2). This variety combines relative earliness to 
Table 2. Mean values for yield components and grain yield characters of 21 cowpea varieties evaluated for 2 years.

\begin{tabular}{|c|c|c|c|c|c|c|c|c|c|c|}
\hline Year/variety & DTF & DTM & PEP & PPE & POL & POP & SPO & HSW & SPP & GYH \\
\hline 2013 & $53.0 \mathrm{~b}$ & $69.3 \mathrm{a}$ & $15.5 \mathrm{a}$ & $3.2 \mathrm{a}$ & $16.0 \mathrm{a}$ & $25.6 \mathrm{a}$ & $15.7 \mathrm{a}$ & $18.8 \mathrm{a}$ & $399.4 a$ & $4,190.7 \mathrm{a}$ \\
\hline 2014 & $54.8 \mathrm{a}$ & $69.8 \mathrm{a}$ & $15.0 \mathrm{a}$ & $3.2 \mathrm{a}$ & $15.8 \mathrm{a}$ & $23.7 b$ & $15.1 \mathrm{a}$ & $18.2 \mathrm{~b}$ & $356.8 \mathrm{~b}$ & $3,644.5 b$ \\
\hline IT04K-227-4 & $46.0 \mathrm{~h}$ & $64.3 f$ & $9.0 \mathrm{j}$ & $1.3 \mathrm{j}$ & $10.9 \mathrm{~h}$ & $8.0 \mathrm{~m}$ & $9.2 \mathrm{j}$ & $18.1 \mathrm{~h}$ & $74.0 \mathrm{~g}$ & $744.1 \mathrm{f}$ \\
\hline IT07K-243-1-2 & $43.7 \mathrm{i}$ & $63.7 \mathrm{~g}$ & $15.8 \mathrm{~d}$ & $4.5 b$ & $17.9 \mathrm{c}$ & $28.5 \mathrm{e}$ & $16.7 \mathrm{c}$ & $18.1 \mathrm{~h}$ & $476.8 \mathrm{c}$ & $4,796.4 b$ \\
\hline IT07K-291-92 & $58.2 \mathrm{c}$ & $72.8 b$ & $10.0 \mathrm{~h}$ & $2.5 \mathrm{f}$ & $15.4 \mathrm{~d}$ & $32.8 \mathrm{c}$ & $14.0 \mathrm{f}$ & $13.7 \mathrm{~m}$ & $119.5 \mathrm{~g}$ & $903.4 \mathrm{f}$ \\
\hline IT07K-299-6 ${ }^{\mathrm{z}}$ & $52.2 \mathrm{f}$ & $66.5 \mathrm{e}$ & $23.0 \mathrm{~b}$ & $5.2 \mathrm{a}$ & $18.1 \mathrm{c}$ & $8.5 \mathrm{~m}$ & $17.9 \mathrm{~b}$ & $19.7 \mathrm{~g}$ & $583.7 \mathrm{~b}$ & $6,389.2 \mathrm{a}$ \\
\hline IT07K-303-1 & $59.7 \mathrm{~b}$ & $72.7 b$ & $19.3 c$ & $3.9 \mathrm{c}$ & $15.1 \mathrm{~d}$ & $28.8 \mathrm{e}$ & $13.5 \mathrm{f}$ & $20.7 d$ & $390.5 d$ & $4,506.0 \mathrm{~b}$ \\
\hline IT08K-125-100 & $58.5 \mathrm{c}$ & $72.2 \mathrm{~b}$ & $9.2 \mathrm{i}$ & $2.3 \mathrm{~g}$ & $14.1 \mathrm{~d}$ & $23.5 \mathrm{~g}$ & $13.3 \mathrm{f}$ & $17.9 \mathrm{~h}$ & $313.5 \mathrm{e}$ & $3,136.7 \mathrm{c}$ \\
\hline IT08K-125-107 & $51.0 \mathrm{~g}$ & $66.7 \mathrm{e}$ & $13.8 \mathrm{~d}$ & $2.5 \mathrm{f}$ & $13.6 \mathrm{e}$ & $27.3 \mathrm{e}$ & $11.8 \mathrm{~h}$ & $18.2 \mathrm{~h}$ & $324.7 d$ & $3,275.3 \mathrm{c}$ \\
\hline IT08K-126-19 & $60.8 b$ & $72.5 b$ & $19.0 \mathrm{c}$ & $3.6 \mathrm{c}$ & $13.6 \mathrm{e}$ & $30.3 d$ & $11.0 \mathrm{i}$ & $20.6 \mathrm{~d}$ & $329.2 d$ & $3,754.1 \mathrm{c}$ \\
\hline IT08K-150-12 & $64.5 \mathrm{a}$ & $88.0 \mathrm{a}$ & $11.3 \mathrm{~g}$ & $2.7 \mathrm{e}$ & $21.4 \mathrm{a}$ & $19.3 \mathrm{i}$ & $13.2 \mathrm{f}$ & $24.9 \mathrm{a}$ & $256.8 \mathrm{f}$ & $3,552.9 \mathrm{c}$ \\
\hline IT08K-150-24 & $53.5 \mathrm{f}$ & $69.5 \mathrm{c}$ & $14.3 \mathrm{~d}$ & $3.2 \mathrm{~d}$ & $13.7 \mathrm{e}$ & $25.8 \mathrm{f}$ & $20.0 \mathrm{~b}$ & $18.2 \mathrm{~h}$ & $517.3 b$ & $5,159.0 \mathrm{~b}$ \\
\hline IT08K-180-11 & $59.0 \mathrm{~b}$ & $71.5 b$ & $12.8 \mathrm{e}$ & $2.7 \mathrm{e}$ & $12.1 \mathrm{~g}$ & $22.7 \mathrm{~g}$ & $13.0 \mathrm{~g}$ & $20.4 \mathrm{e}$ & $296.3 f$ & $3,342.5 c$ \\
\hline IT09K-231-1 & $56.0 \mathrm{e}$ & $67.0 \mathrm{~d}$ & $9.8 \mathrm{~h}$ & $1.9 \mathrm{~h}$ & $15.6 \mathrm{~d}$ & $17.5 \mathrm{k}$ & $23.0 \mathrm{a}$ & 14.31 & $401.7 d$ & $3,216.4 \mathrm{c}$ \\
\hline IT10K-815- $5^{\text {z) }}$ & $57.7 d$ & $69.1 \mathrm{c}$ & $17.8 \mathrm{c}$ & $3.9 \mathrm{c}$ & $15.5 \mathrm{~d}$ & $37.3 b$ & $14.3 \mathrm{e}$ & $21.4 \mathrm{c}$ & $536.3 b$ & $6,385.0 \mathrm{a}$ \\
\hline IT10K-817-7 & $60.3 b$ & $69.6 \mathrm{c}$ & $23.0 \mathrm{~b}$ & $4.8 \mathrm{a}$ & $13.1 \mathrm{f}$ & $34.0 \mathrm{c}$ & $15.2 d$ & $22.8 b$ & $522.5 b$ & $6,187.9 \mathrm{a}$ \\
\hline IT10K-827-11 & $45.0 \mathrm{~h}$ & $59.2 \mathrm{~h}$ & $15.2 \mathrm{~d}$ & $3.1 \mathrm{~d}$ & $12.3 \mathrm{~g}$ & $25.7 f$ & $12.3 \mathrm{~h}$ & $17.8 \mathrm{~h}$ & $316.3 \mathrm{e}$ & $3,131.6 \mathrm{c}$ \\
\hline IT10K-832-3 & $52.7 \mathrm{f}$ & $65.8 \mathrm{e}$ & $12.7 \mathrm{e}$ & $2.8 \mathrm{e}$ & $15.7 \mathrm{~d}$ & $16.0 \mathrm{k}$ & $18.2 b$ & $16.7 \mathrm{j}$ & $287.3 f$ & $2,669.9 d$ \\
\hline IT10K-836-4 & $52.0 \mathrm{f}$ & $72.3 b$ & $13.7 d$ & $2.9 \mathrm{e}$ & $17.7 \mathrm{c}$ & $21.5 \mathrm{~h}$ & $12.3 \mathrm{~h}$ & $20.1 \mathrm{f}$ & $264.2 f$ & $2,949.9 \mathrm{c}$ \\
\hline IT $10 \mathrm{~K}-837-1^{\mathrm{y})}$ & $45.5 \mathrm{~h}$ & $58.2 \mathrm{~h}$ & $22.0 \mathrm{~b}$ & $4.5 b$ & $17.6 \mathrm{c}$ & $32.3 \mathrm{c}$ & $15.8 \mathrm{c}$ & $21.0 \mathrm{~d}$ & $511.3 b$ & $5,969.0 \mathrm{a}$ \\
\hline IT10K-843 & $52.0 \mathrm{f}$ & $68.0 \mathrm{~d}$ & $11.7 \mathrm{f}$ & $2.7 \mathrm{e}$ & $18.6 b$ & $18.7 \mathrm{j}$ & $17.9 \mathrm{~b}$ & $17.2 \mathrm{i}$ & $334.0 \mathrm{~d}$ & $3,204.3 \mathrm{c}$ \\
\hline IT10K-866-1 & $52.3 \mathrm{f}$ & $87.3 \mathrm{a}$ & $10.3 \mathrm{~h}$ & $1.3 \mathrm{j}$ & $19.8 b$ & $14.7 \mathrm{j}$ & $22.8 \mathrm{a}$ & $12.3 n$ & $320.7 d$ & $2,260.6 \mathrm{e}$ \\
\hline IT11K-61-82 & $50.5 \mathrm{~g}$ & $60.3 \mathrm{~h}$ & $26.0 \mathrm{a}$ & $4.6 \mathrm{a}$ & $21.5 \mathrm{a}$ & $43.7 \mathrm{a}$ & $17.3 \mathrm{c}$ & $16.0 \mathrm{k}$ & $755.0 \mathrm{a}$ & $6,735.7 \mathrm{a}$ \\
\hline
\end{tabular}

Mean values with the same letters in a column (for year or variety) as not significantly different $(P<0.05)$ according to Duncan's multiple range test.

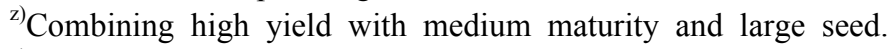

${ }^{\mathrm{y})}$ Combining high yield with early maturity and large seed.

${ }^{\mathrm{x})}$ Combining high yield with earl maturity and medium seed.

DTF: days to flowering, DTM: days to pod maturity, PEP: peduncles per plant, PPE: pods per peduncle, POL: pod length (cm), POP: pods per plant, SPO: seeds per pod, HSW: 100-seed weight (g), SPP: seeds per plant, GYH: grain-seed yield per hectare $(\mathrm{kg})$.

flowering (51 days) and pod maturity (60 days), with a medium sized seed type $(0.16 \mathrm{~g} / \mathrm{seed})$. Longest pods $(21.4$ $\mathrm{cm})$ and largest seeds (24.9 g/100-seed weight) were obtained from IT08K-150-12. IT04K-227-4 recorded lowest values for most of the yield components, for example, seed yield (744 $\mathrm{kg} \mathrm{ha}^{-1}$ ). Variety(ies) with combination of superior traits are identified for selection (Table 3) and details presented under discussion section.

Correlation analysis of yield components indicates highly significant positive relationship between days to flowering (period of anthesis) and pod maturity period (Table 3 ). Seed size (100-seed weight) also recorded highly significant positive correlation with days to anthesis.
However, days to pod maturity recorded significant negative correlations with peduncles per plant, pods per peduncle, pods per plant, seeds per plant and total grain-seed yield. Except flowering and maturity, all other the yield components recorded highly significant positive correlations with grain seed yield (Table 3). Seed size (100-seed weight) recorded significant negative correlation with seeds per pods, but not significant with seeds per plant.

Analysis of genetic variance components of all the yield components indicated that most of the phenotypic variability $\left(\sigma^{2} p\right)$ recorded among these 21 cowpea varieties are genetic and with very high heritability (broad sense) (Table 4). The magnitude of error variance (environment, 
Table 3. Genetic correlation coefficients analysis of 10 seed yield and yield components in cowpea.

\begin{tabular}{|c|c|c|c|c|c|c|c|c|c|c|}
\hline Characteristic & $\begin{array}{l}\text { Days to } \\
\text { flowering }\end{array}$ & $\begin{array}{l}\text { Days to } \\
\text { maturity }\end{array}$ & $\begin{array}{l}\text { Peduncles } \\
\text { per plant }\end{array}$ & $\begin{array}{l}\text { Pods per } \\
\text { peduncle }\end{array}$ & $\begin{array}{l}\text { Pod } \\
\text { length } \\
(\mathrm{cm})\end{array}$ & $\begin{array}{c}\text { Pods } \\
\text { per plant }\end{array}$ & $\begin{array}{l}\text { Seeds } \\
\text { per pod }\end{array}$ & $\begin{array}{c}\text { Hundred } \\
\text { seed } \\
\text { weight }\end{array}$ & $\begin{array}{c}\text { Seeds } \\
\text { per plant }\end{array}$ & $\begin{array}{c}\text { Grain yield } \\
\text { per hectare } \\
(\mathrm{kg})\end{array}$ \\
\hline Days to flowering & 1.00 & & & & & & & & & \\
\hline Days to maturity & $0.63 * *$ & 1.00 & & & & & & & & \\
\hline Peduncles per plant & $-0.07 \mathrm{~ns}$ & $-0.36^{* *}$ & 1.00 & & & & & & & \\
\hline Pods per peduncle & $-0.05 \mathrm{~ns}$ & $-0.34 * *$ & $0.80 * *$ & 1.00 & & & & & & \\
\hline Pod length $(\mathrm{cm})$ & $-0.00 \mathrm{~ns}$ & $0.25^{* *}$ & $0.17 \mathrm{~ns}$ & $0.18^{*}$ & 1.00 & & & & & \\
\hline Pods per plant & $-0.01 \mathrm{~ns}$ & $-0.30 * *$ & $0.80^{* *}$ & $0.73 * *$ & $0.18^{*}$ & 1.00 & & & & \\
\hline Seeds per pod & $-0.07 \mathrm{~ns}$ & $0.10 \mathrm{~ns}$ & $0.00 \mathrm{~ns}$ & $-0.02 \mathrm{~ns}$ & $0.37 * *$ & -0.01 & 1.00 & & & \\
\hline Hundred seed weight & $0.29 * *$ & $0.09 \mathrm{~ns}$ & $0.33 * *$ & $0.42 * *$ & $-0.06 \mathrm{~ns}$ & $0.37 * *$ & $-0.44^{* *}$ & 1.00 & & \\
\hline Seeds per plant & $-0.09 \mathrm{~ns}$ & $-0.27^{* *}$ & $0.71 * *$ & $0.65^{* *}$ & $0.34 * *$ & $0.86^{* *}$ & $0.46^{* *}$ & $0.11 \mathrm{~ns}$ & 1.00 & \\
\hline $\begin{array}{l}\text { Grain yield per } \\
\text { hectare }(\mathrm{kg})\end{array}$ & $0.01 \mathrm{~ns}$ & $-0.22 *$ & $0.76^{* *}$ & $0.74 * *$ & $0.26^{* *}$ & $0.89 * *$ & $0.29 * *$ & $0.41 * *$ & $0.95 * *$ & 1.00 \\
\hline
\end{tabular}

${ }^{*} r(124)=0.174, P<0.05 ; * * r(124)=0.228, P<0.01$.

ns: not significant.

Table 4. Genetic variance components analysis of 10 yield components and grain yield characters of 21 cowpea varieties.

\begin{tabular}{lccccccc}
\hline \hline \multicolumn{1}{c}{ Characteristic } & $\sigma^{2} \mathrm{~g}^{\mathrm{z}}$ & $\sigma^{2}$ gxy & $\sigma^{2} \mathrm{e}$ & $\sigma^{2} \mathrm{p}$ & $\mathrm{GCV}$ & $\mathrm{PCV}$ & $h^{2}(\%)$ \\
\hline Days to flowering & 33.0 & 2.2 & 3.0 & 38.2 & 10.3 & 11.5 & 86.0 \\
Days to maturity & 55.93 & 7.9 & 4.8 & 68.6 & 10.8 & 11.9 & 82.0 \\
Peduncles per plant & 25.6 & 0.5 & 3.0 & 29.1 & 33.2 & 35.4 & 88.0 \\
Pods per peduncle & 1.2 & 0.0 & 0.3 & 1.4 & 34.5 & 37.5 & 85.0 \\
Pod length (cm) & 8.7 & 0.2 & 1.7 & 10.5 & 18.6 & 20.5 & 82.0 \\
Pods per plant & 81.3 & 6.4 & 8.2 & 95.9 & 36.6 & 39.8 & 85.0 \\
Seeds per pod & 12.9 & 0.1 & 4.3 & 17.0 & 23.4 & 26.9 & 75.0 \\
Hundred seed weight & 8.7 & 0.7 & 0.1 & 9.5 & 15.9 & 16.7 & 91.0 \\
Seeds per plant & $24,233.4$ & $1,473.1$ & $3,785.1$ & $29,491.7$ & 41.2 & 45.4 & 82.0 \\
Grain yield per hectare $(\mathrm{kg})$ & $2,914,298.7$ & $170,505.7$ & $419,993.7$ & $3,504,798.1$ & 43.6 & 47.8 & 83.0 \\
\hline
\end{tabular}

${ }^{2)} \sigma^{2}$ g: Genotypic variance, $\sigma^{2}$ gxy: Genotype $\times$ environment variance, $\sigma^{2}$ : Environmental variance, $\sigma^{2} \mathrm{p}$ : Phenotypic variance. GCV: Genotypic coefficient of variation, PCV: Phenotypic coefficient of variation, $h^{2}$ : Heritability (broad sense).

$\sigma^{2}$ e; and interaction effect, $\sigma^{2}$ g x y) was significantly lower compared to the genotypic variance for all the plant traits. The data also showed higher phenotypic coefficient of variation (PCV) compared to GCV across all the yield components studied. Estimates of heritability (broad sense) for these yield components indicated that seed size recorded highest heritability value $(91.0 \%)$, while the least heritability $(75.0 \%)$ was recorded for seeds per pod.

\section{DISCUSSION}

Expression of wide genetic variability has recorded in this study offers opportunity for quality improvement that would allow selection of individuals with better attributes for maturity period and seed yield. Data on wide genetic variability in cowpea for morphological (phenotypic) attributes are well documented (Apte et al. 1987; Damarany 1994; Idahosa et al. 2010; Manggoel et al. 2012; Nwosu et al. 2013). The results obtained here is in slight contrast to study by Nwosu et al. (2013) that showed non-significant effect of location for all yield components 
including flowering and maturity periods in six varieties of cowpea evaluated in Keffi (guinea savannah ecology) and Ibadan (tropical rainforest ecology). This kind of variation between studies could be attributed to sample size, genotype, and factors of location instead of years as in this study. However, there are two categories of yield components identified in cowpea when the two data set were compared; i.e., the environmentally influenced (sensitive) components (like pods per plant, 100-seed weight, seeds per plant, and total seed yield per hectare) and environmentally non-sensitive type (like pod maturity, peduncles per plant, pods per peduncle, and pod length). The former are significantly affected by variation in climatic variables across and/or within seasons, while the latter exhibited some degree of tolerance (for climatic fluctuation) and stability across locations and/or years. In other words, effect of climatic variables like sunlight, soil moisture, relative humidity and temperature are more critical during the seed formation and development in cowpea.

An overview of the degree of variation obtained for the 21 cowpea lines/varieties in this data as depicted by CVs (\%) and range values for the yield components could be a reflection of selection spectrum for improvement on the one hand and/or a measure of instability on the other hand. Traits with lower CVs are more stable across years than those with large CVs (Table 1). Importantly, the nature of variation recorded here offers opportunity for selection of superior candidates (varieties) for short- and long-term use and yield improvement (high and stable) in cowpea.

Slight variation recorded in flowering period between the years is of little biological consequence as it does not affect maturity period. Perhaps seed yield being final product of complex physiological and development processes from sowing to maturity (Oladejo et al. 2011), accumulated significant effect of other components to record highest variation between the years (Table 1). This development is not unexpected considering the dynamic nature of climatic variables and its complex interplay with biological properties of plant. This result corroborates Nwosu et al. (2013) that reported about 54 days to flowering and 70 days pod maturity in 6 cowpea varieties evaluated in Ibadan (tropical-transition rain forest) and
Keffi (guinea savannah). The preponderance of individuals with early-medium maturity and absence of individuals with very prolonged (delay) flowering and indeterminate fruiting characteristics deed indicate that these cowpea varieties are products of advance breeding program for earliness and determinate flowering and fruiting characteristics. Naturally, cowpea plant is sensitive to day-length but recent genetic improvement had led to development of day-neutral varieties (Akande et al., 2012), which can be planted anytime of the year provided there is sufficient available moisture. However, improved cowpea varieties must combine high grain yield, erect growth habit, determinate growth pattern and early to medium maturity cycle (Singh 2007; Machado et al. 2008). These combined attributes were identified in 6 of these 21 cowpea varieties (Table 2) and discussed below.

Although yield is principal goal of many crop breeding programs especially in the tropics, but multiple traits package determines varietal/cultivar acceptability by cowpea farmers and/or primary consumers. For example, large (size) seeds with rough testa are preferred by consumers and cultivars with large seed number per pod/plant with short gestation are important to farmers/ growers for higher yield and multiple planting cycles per year. Therefore development of improved varieties should include these traits along seed-grain yield (Redden et al. 1984; Drabo et al. 1985; Singh 2007; Machado et al. 2008; Ribeiro et al. 2014). In this study, five (5) varieties (IT07K-299-6, IT08K-150-24, IT10K-815-5, IT10K-817-7 and IT10k-837-1 showed high potential for the combination of early-medium pod maturity (60-70 days), high yield $\left(>5,000 \mathrm{~kg} \mathrm{ha}^{-1}\right)$ with large seeds $(>0.18 \mathrm{~g} /$ seed $)$, thus suitable for multiple traits package as improved cowpea varieties. However, 1T11K-61-82 with highest seed yield $\left(6,735 \mathrm{~kg} \mathrm{ha}^{-1}\right)$ fell short of this standard because of medium seed size $(0.16 \mathrm{~g})$. Cowpea seeds are classified into small ( $<12 \mathrm{~g} / 100$ seeds), medium (12-18 g/100 seeds) and large ( $>18 \mathrm{~g} / 100$ seeds) (Drabo et al. 1984). With wide variability recorded for seed size in this study and high crossability among Vigna species, IT11K-61-82 could be significantly improved for seed size in the short term through hybridization with either IT10K-817 or IT10K-815-5 with seed weight of $0.23 \mathrm{~g}$ and $0.21 \mathrm{~g}$, 
respectively. Sene (1968) had reported six pairs of genes acting additively for seed weight in cowpea and each gene corresponds to a weight increase of $1.1 \mathrm{~g}$ per seed (Drabo et al. 1984). Based on the following criteria, high yielding ( $>5,000 \mathrm{~kg} / \mathrm{ha}$ ), early maturing ( $<60$ days pod maturity), medium maturity (60-70 days pod maturity), large seed ( $>$ $18 \mathrm{~g} / 100$-seed weight), and medium seed (12-17.4 $\mathrm{g} / 100$-seed weight), three superior varietal groups are identified. (i) IT10K-837-1, combines very high seed yield with early maturity and large seed, (ii), IT07K-299-6, IT10K-815-5, IT10K817-7, and IT08K-150-24, combine very high seed yield with medium maturity and large seeds, and (iii) IT11K-61-82, combines very high seed yield with early maturity and medium seeds.

Data obtained here indicated that flowering period had a strong genetic linkage with pod maturity in determinate fruiting cowpea biotypes and could be used as a selection factor. However, significant negative relationships between seed yield components and pod maturity period suggest that prolong vegetative phase could have negative effect on yield components and seed yield in cowpea. In other words, variety with a long gestation cycle have tendency to flower and produce pods towards dry period when soil moisture may not be sufficient for optimum seed development and consequently resulting in low yield. Moreover, water stress could lead to a decrease in plant water content, turgor reduction, decreasing cellular expansion and alteration of metabolic processes that affect growth and yield in plant (Pimentel 2004; Costa et al. 2008). In fact, Abayomi and Abidoye (2009) had reported significant negative relationships between soil moisture deficit; and growth and reproductive traits in cowpea. With characteristic dry nature and poor rainfall pattern of guinea savannah ecology, cowpea varieties with early-medium maturing period (40-70 days) would be most appropriate for this location and 6 high yielding varieties identified in this study met this criterion.

Data presented here also show that faster improvement with high genetic advancement in seed yield would be achieved in cowpea breeding program because of (i) significant positive correlations between yield components and seed yields (Table 3 ) and (ii) high heritabilities (Table 4). Ogunbodede (1989) had reported similar significant
( $P=0.01)$ and positive correlation between yield and other yield related traits in cowpea except for threshing percentage. For example, increased peduncles and pods per plants could lead to increased seeds per plant. However, in order of magnitude, seeds per plant and pods per plants were the most significantly correlated traits $(r=0.95,0.89$, $P=0.01$ ) with yield (i.e., most contributory factors), a trend that corroborates Ogunbodede (1989). Seed size also contributed significantly to total seed yield $(\mathrm{kg} / \mathrm{ha})$ in cowpea as evident in this study and Ogunbodede's data (Ogunbodede 1989). Taking together, it therefore possible to breed cowpeas that combine large seed size with high yield, although seed size recorded negative correlations with seeds per pods but not with seeds per plants (Ogunbodede 1989; Table 3 this data). Rachie and Roberts (1974) and Drabo et al. (1985) reported similar negative correlations between seed size and seeds per pod. While large seeds could be constrained by seed per pods (negative correlation), improvement for combining high yield and large seed could be achieved through breeding for increased number of pods per plant. Generally, seed number-size trade-off has been a controversial phenomenon in studies of some angiosperms, e.g., potentilla, Potentilla reptans (Stuefer et al. 2002), quercus, Quercus ilex (Gómez 2004), cashew, Anarcadium occidentale (Aliyu and Awopetu 2011) and wheat, Triticum spp (Griffiths et al. 2015), the non-concurrence of negative relationships between seed size and seeds per plant with seeds per pod in this study suggest a very weak genetic linkage and/or trade-off between size and number in cowpea. However, with strong correlation (linkage) between number (seeds per pod/plant) and yield (Ogunbodede 1989; this data) and additive nature of genes for seed size (Drabo et al. 1984; 1985), element of trade-off could be well managed during cowpea yield improvement, as seed size and grain seed yield could be effectively and systematically combined in a breeding program.

Looking at the magnitude of high genotypic variance compared to error variance (environment, $\sigma^{2} \mathrm{e}$ and interaction effect, $\sigma^{2} \mathrm{~g} \mathrm{x}$ y) obtained here, it is evident that major contributor of total variance for these plant traits are more genetic than non-genetic, thus, signifying a high latitude for improvement through selection. Similar pattern 
of high genetic variance had been observed in other crop species, e.g., sunflower, Heliathus annuus (Singh and Yadava 1986); vernonia, Vernonia amygladina (Baye 2000); cowpea (Nwofia et al. 2006) and pawpaw, Carica papaya (Nwofia and Okwu 2012). Higher PCV compared to GCV across all the yield components is an indication of genotype by environment $(\mathrm{G} \times \mathrm{E})$ interaction for these plant phenotypic traits. High heritability estimates as obtained here is a measure of stability in the phenotypic expression of these plant characters through space and time and possible genetic advancement for cowpea yield. Past genetic studies in cowpea had shown broad sense heritability ranging between $48 \%$ and $82 \%$ for seed size (Leleji 1976), 48\% and 90\% for seed size, 21 and $82 \%$ for seeds per pod (Drabo et al. 1985). Nwofia and Okwu (2012) reported broad sense heritability of between $79.6 \%$ and $99.9 \%$ in pawpaw. Johnson et al. (1955) had opined that high heritability would be a reliable measure of predicting stability and effectiveness of selection. In this case, seed size is the most stable (i.e., with less environmental influence) among the seed yield components in cowpea.

Finally, suffice to say that with good agronomic practices (timely planting, weeding, pest management, nutrient supplementation, and timely harvesting), advance (improved) cowpea lines (varieties) would maintain stable yield over generations and years. In the opinion of Drabo et al. (1985), the preponderance of additive gene effects, the large broad sense heritability, and small correlations (negative) between seed size and seeds per pod, indicate that simultaneous improvement of the two characters can be achieved by conventional selection procedures. In other words, six (6) varieties (IT10K-837-1, IT07K-299-6, IT10K-815-5, IT10K817-7, IT08K-150-24, and IT11K-61-82) that combine multiple quality acceptable (consumers and/farmers) traits identified in this 2 years study could be release to cowpea farmers in the southern guinea savannah agro-ecology and also used in future long-term genetic improvement of cowpea.

\section{ACKNOWLEDGEMENTS}

The authors appreciate the support of Genetic Resources Unit and Legumes Improvement Program of the International Institute of Tropical Agriculture (IITA), Ibadan for supply of experimental planting materials. We also acknowledged the technical supports of Dr. K. Fasakin, Mr. B. Adegbosin, and Mr. A. Adekunle of College of Agriculture, Kwara State University, Malete.

\section{REFERENCES}

Abayomi YA, Abidoye TO. 2009. Evaluation of cowpea genotypes for soil moisture stress tolerance under screen house condition. Afr. J. Plant Sci. 3: 229-237.

Akande SR, Olakojo SA, Ajayi SA, Owolade OF, Adetumbi JA, Adeniyan ON, et al. 2012. Planting date affects cowpea seed yield and quality at southern guinea savanna, Nigeria. Seed Technol. 34: 51-60.

Alghali AM. 1991. Studies of cowpea farming in Nigeria with emphasis on insect pest control. Trop. Pest Management 37: 71-74.

Aliyu OM, Awopetu JA. 2011. Variability study on nut size and number trade-off identify a threshold level for optimum yield in cashew (Anacardium occidentale L.). Int. J. Fruit Sci. 11: 342-363.

Allard RW. 1999. Principles of plant breeding. $2^{\text {nd }}$ ed. John Wiley \& Son, New York, NY.

Apte UB, Chavan SA, Jadhav BB. 1987. Genetic variability and heritability in cowpea. Indian J. Agric. Sci. 57: 596-598.

Aryeetey AN, Laing E. 1973. Inheritance of yield components and their correlation with yield in cowpea (Vigna unguiculata L. Walp.). Euphytica 22: 386-392.

Baye T. 2000. Genotypic and phenotypic variability in Vernonia galamensis germplasm collected from Eastern Ethopia. J. Agric. Sci. (Cambridge) 139: 161-168.

Boukar O, Massawe F, Muranaka S, Franco J, Maziya-Dixon B, Singh B, et al. 2011. Evaluation of cowpea germplasm lines for protein and mineral concentrations in grains. Plant Genet. Resour. 9: 515-522.

CoStat. CoHort Software [Internet], CoHort Software, Monterey, CA. [cited 2016 Apr 14]. Available from: 
http://www.cohort.com/costat.html

Costa RCL, Lobato AKS, Oliveira Neto CF, Maia PSP, Alves GAR, Laughinhouse HD. 2008. Biochemical and physiological responses in two Vigna unguiculata (L.) Walp. Cultivars under water stress. J. Agron. 7: 98-101.

Damarany AM. 1994. Estimates of genotypic phenotypic correlation, heritability and potency of gene set in cowpea (Vigna unguiculata L., Walp.). Assuit J. Agric. Sci. 25: 1-8.

Drabo I, Redden R, Smithson JB, Aggarwal VD. 1984. Inheritance of seed size in cowpea (Vigna unguiculata L. Walp.). Euphytica 33: 929-934.

Drabo I, Ladeinde TAO, Redden R, Smithson JB. 1985. Inheritance of seed size and number per pod in cowpeas (Vigna unguiculata L. Walp.). Field Crops Res. 11: 335-344.

FAO. 2013. Food and Agricultural Organization Production Statistics for 2012 [Internet]. [cited 2015 Jun 23]. Available from: http://faostat.fao.org/site/339/default.aspx.

Griffiths S, Wingen L, Pietragalla J, Garcia G, Hasan A, Miralles D, et al. 2015. Genetic dissection of grain size and grain number trade-offs in CIMMYT wheat germplasm. PLoS One 10: e0118847.

Gómez JM. 2004. Bigger is not always better: conflicting selective pressures on seed size in Quercus ilex. Evolution 55: 71-80.

Idahosa DO, Alika JE, Omoregie AU. 2010. Genetic variability, heritability and expected genetic advance as indices for yield and yield components selection in cowpea (Vigna unguiculata L., Walp). Acad. Arena 2: 22-26.

Johnson HW, Robinson HF, Comstock RE. 1955. Estimates of genetic and environmental variability in soybeans. Agron. J. 47: 314-318.

Kumar A, Misra SC, Singh YP, Chuahan BPS. 1985. Variability and correlation studies in triticale. $\mathrm{J}$. Maharashtra Agric. Uni. 10: 273-275.

Leleji O. 1976. Inheritance of three agronomic characters of cowpea (Vigna unguiculata L. Walp). Samaru Bull. 252.

Machado CF, Teixeira NJP, Freire Filho FR, Rocha MM, Gomes RLF. 2008. Identificação de genótipos de feijão caupi quanto à precocidade, arquitetura da planta e produtividade de grãos (identification of genotypes of Cowpea beans as for precocity, plant architecture and grain productivity). Rev. Ciênc. Agron. 39: 114-123.
Manggoel W, Uguru MI, Ndam ON, Dasbak MA. 2012. Genetic variability, correlation and path coefficient analysis of some yield components of ten cowpea (Vigna unguiculata L., Walp) accessions. J. Plant Breed. Crop Sci. 4 : 80-86.

Nwofia GE, Ene-Obong EE, Okocha PI. 2006. Genotypic and phenotypic variability in cowpea grown in a humid environment in Nigeria. Trop. Sci. 46: 82-86.

Nwofia GE. 2012. Yield and yield components in vegetable cowpea on an ultisol. Afr. J. Agric. Res. 7: 4097-4103.

Nwofia GE, Okwu QU. 2012. Studies on nutritive characteristics and variability in pawpaw (Carica papaya L.). Pak. J. Nutr. 11: 957-962.

Nwosu DJ, Olatunbosun BD, Adetiloye IS. 2013. Genetic variability, heritability, and genetic advance in cowpea genetotypes in two agro-ecological environments. Greener J. Biol. Sci. 3: 202-207.

Ogunbodede BA. 1989. Comprison between three methods of determining the relationships between yield and eight of its components in cowpea, Vigna unguiculata L. Walp. Sci. Hortic. 38: 201-205.

Oladejo AS, Akinwale RO, Obisesan IO. 2011. Interrelationships between grain yield and other physiological traits of cowpea cultivars. Afr. Crop Sci. J. 9: 189-200.

Pickaard CS, Scheid OM. 2013. Epigenetic regulation in plants. Cold Spring Harb. Perspect. Biol. 6: a019315, $1-32$.

Pimentel C. 2004. The relation of the plant with water. EDUR, Seropédica 2004.

Prasad SR, Prakash R, Sharma CM, Haque MF. 1981. Genotypic and phenotypic variability in quantitative characters in oat. Indian J. Agric. Sci. 51: 480-482.

Rachie KO, Roberts LM. 1974. Grain legumes of the lowland tropics. Adv. Agron. 26: 1-132.

Redden R, Drabo I, Aggarwal V. 1984. IITA programme of breeding cowpeas with acceptable seed types and disease resistance for West Africa. Field Crop Res. 8: 35-48.

Ribeiro HLC, Boiteux LS, Santos CAF. 2014. Genetic parameters of earliness and plant architecture traits suitable for mechanical harvesting of cowpea (Vigna unguiculata L.). Aust. J. Crop Sci. 8: 1232-1238.

Santos CAF, Campos da Costa DC, Roberto da Silva W, Boiteux LS. 2012. Genetic analysis of total seed protein content in two cowpea crosses. Crop Sci. 52: 2501-2506.

Sene D. 1968. Héridité du poids de 100 grains chez Vigna 
unguiculata (L.) Walp. (Cowpea). Agron. Trop. 23: 1345-1351.

Singh BB. 2007. Recent progress in cowpea genetics and breeding. Acta Hortic. 752: 69-76.

Singh JV, Yadava TP. 1986. Variability studies of some quantitative characters in sunflower. J. Oilseed Res. 3: 125-127.

Stuefer JF, Van Hulzen JB, During HJ. 2002. A geneotypic trade-off between the number and size of clonal off-spring in the stoloniferous herbs Potentilla reptans. J.
Evol. Biol. 15: 880-884.

Umaharan P, Ariyanayagam RP, Haque SQ. 1997. Genetic analysis of yield and its components in vegetable cowpea (Vigna unguiculata L. Walp). Euphytica 96: 207-213.

Warner DJ, Honma S. 1980. Inheritance of leaf geometry in cauliflower. J. Hered. 71: 105-109.

Wricke G, Weber WE. 1986. Quantitative genetics and selection in plant breeding. Walter de Guyter $\mathrm{GmbH}$, Berlin, Germany. 